\title{
Kebahagiaan Menurut Syeikh Ibnu Atha'illah as-Sakandari
}

\author{
Ade Anang Suhada ${ }^{1}$, Muliadi $^{2}$, Dodo Widarda ${ }^{3}$ \\ 1,2,3 Fakultas Ushuluddin UIN Sunan Gunung Djati Bandung, Indonesia \\ adeanangsuhada98@gmail.com,muliadi1@uinsgd.ac.id, \\ dodowidarda@gmail.com
}

\begin{abstract}
The hustle and bustle of the modern era, marked by an easy life, is relatively only able to provide physical pleasure, but is unable to provide physical and spiritual happiness. The phenomenon of life that is not balanced with this level of happiness, causes a void. The purpose of this study was to determine the meaning and ways of obtaining happiness according to Syeikh Ibnu Atha'illah as-Sakandari, as well as its relevance to human life in the modern era. This research is a qualitative research that uses a library research approach. The analytical method used is a content analysis technique. The conclusion of this study, shows that the happiness referred to by Syeikh Ibnu Atha'illah as-Sakandari divided happiness in two dimensions, namely happiness in the World and happiness in the hereafter. Happiness actually exists in human. Happiness will be realized when humans are able to optimize the potential of the mind and the potential of the heart. The path to happiness can be attained by knowing the characteristics of the wordly life and suffering and reducing pleasures. Moral perfections will lead humans to true happiness, namely meeting Allah SWT in a state of faith.
\end{abstract}

Keywords: Happiness, Heart potential, Library research, Mind potential, Morals.

\begin{abstract}
Abstrak
Ingar-bingar yang terjadi di era modern, ditandai dengan kehidupan yang serba mudah, relatif hanya mampu memberikan kesenangan lahiriah semata, namun tidak mampu memberikan kebahagiaan jasmani dan rohani. Fenomena kehidupan yang tidak seimbang dengan tingkat kebahagiaan ini, menyebabkan suatu kehampaan. Tujuan penelitian ini adalah untuk mengetahui makna dan cara memperoleh kebahagiaan menurut Syeikh Ibnu Atha' illah asSakandari, serta relevansinya dengan kehidupan manusia di era modern. Penelitian ini adalah penelitian kualitatif yang
\end{abstract}


menggunakan pendekatan studi pustaka (library research). Metode analisis yang digunakan merupakan teknik analisis konten (content analysis). Hasil dan pembahasan penelitian ini, menunjukan bahwa kebahagiaan yang dimaksud oleh Syeikh Ibnu Atha'illah as-Sakandari merujuk pada kebahagiaan dua dimensi, yaitu kebahagiaan di dunia dan kebahagiaan di akhirat. Kebahagiaan tersebut sejatinya telah ada di dalam diri manusia. Kebahagiaan akan terwujud ketika manusia mampu mengoptimalkan potensi akal dan potensi hati. Jalan untuk memperoleh kebahagiaan bisa diraih dengan mengenal karakteristik kehidupan dunia serta menekan dan mengurangi berbagai kesenangan. Kesempurnaan akhlak akan mengantarkan manusia pada kebahagiaan hakiki, yaitu berjumpa dengan Allah SWT dalam keadaan iman.

Kata kunci: Akhlak, Kebahagiaan, Potensi akal, Potensi hati, Studi pustaka.

\section{Pendahuluan}

Manusia tidak terlepas dari berbagai macam persoalan dan problematika kehidupan. Tidak hanya itu, kehidupan manusia pun selalu diwarnai dengan berbagai macam keinginan dan harapan. Harapan terbesar manusia adalah kebahagiaan (Hamim, 2016). Keanekaragaman manusia, serta dinamika kehidupan yang berbeda-beda menjadi salah satu faktor perbedaan makna kebahagiaan. Bagi sebagian orang, harta kekayaan adalah suatu kebahagiaan, sebagian lainnya beranggapan bahwa karir dan jabatan adalah kebahagiaan, bahkan terhindar dari berbagai macam masalah sekalipun adalah kebahagiaan. Jika kehidupan tidak seimbang dengan tingkat kebahagiaan, kehidupan manusia akan berdampak pada kehampaan (Iman Setiadi Arif, 2018). Abad ke-21 ditandai dengan kemajuan ilmu pengetahuan, teknologi yang semakin cepat dan serba memadai. Namun, hal tersebut tidak mampu memenuhi kebutuhan manusia dalam tercapainya kebahagiaan. Di zaman modern, banyak manusia yang dilanda kegelisahan, kecemasan, stress, dan berbagai macam penyakit kejiwaan (Tamami, 2011). Orientasi terhadap materi dan keduniaan, tampaknya hanya menambah beban dan menyebabkan disorientasi terhadap makna kebahagiaan itu sendiri. Seperti apa yang dikatakan oleh Sayyed Hossein Nasr, bahwa manusia modern tengah mengalami kehampaan spiritual, krisis makna, dan mengalami keterasingan, hal tersebut menyebabkan manusia modern kehilangan harapan akan kebahagiaan di masa depan seperti yang dijanjikan oleh renaisans, pencerahan, saintisme serta teknologisme (Haidar Bagir, 2006). 
Di saat materialisme menguasai kehidupan manusia, telah terjadi redefinisi terhadap ukuran kebahagiaan. Hal ini ditandai dengan bunuh dirinya seorang aktor terkenal peraih Oscar, Robin William. Komponen-komponen yang selama ini dianggap sebagai ukuran kebahagiaan dan kesuksesan, seperti kekayaan dan kekuasaan, perlu untuk diartikan secara lebih mendasar (Muskinul Fuad, 2018).

Terdapat banyak penelitian terdahulu yang membahas kebahagiaan, baik dari sudut pandang tasawuf maupun filsafat. Penelitian tersebut antara lain, penelitian yang dilakukan oleh Ida Rodiah (2017) yang berjudul "Konsep Kebahagiaan Menurut Hamka." Esensi penelitian tersebut adalah kebahagiaan bisa diperoleh melalui empat hal, yaitu iman dengan sebenar-benarnya, agama, keinginan yang bersih, dan mempunyai keyakinan (Ida Rodiah, 2017). Selanjutnya, penelitian yang dilakukan oleh Jarman Arroisi (2019) yang berjudul "Bahagia dalam Perspektif al-Ghazali" yang diterbitkan dalam Kalimah: Jurnal Studi Agama-Agama dan Pemikiran Islam Universitas Darussalam Gontor. Jarman Arroisi (2019) menjelaskan, kebahagiaan merupakan suatu perasaan yang timbul dalam jiwa seseorang melalui perjuangan bersunguh-sungguh. Jalan untuk menempuhnya ialah makrifat an-nafs dan puncaknya ialah makrifat Allah. Kebahagiaan ini akan dirasakan setelah mencapai kesempurnaan jiwa rasionalnya. Jiwa rasional tersebut akan seimbang dengan cara menjaga amalan-amalan baik ketika di dunia. Kebahagiaan sejati adalah kebahagiaan jiwa natural yang diperoleh melalui riyadhoh dan mujahadah dan bukan terletak pada materi (Jarman Arroisi, 2019). Selanjutnya, penelitian yang dilakukan oleh Endrika Widdia Putri (2018) dengan judul "Konsep Kebahagiaan Menurut alFarabi" yang dimuat dalam Jurnal Tsaqafiyyat UIN Sunan Kalijaga. Penelitian ini menjelaskan bahwa kebahagiaan merupakan kebaikan untuk kebaikan itu sendiri dan merupakan tujuan akhir dari segala aktivitas di muka bumi. Orang yang hendak mencapai kebahagiaan, terlebih dahulu harus memperbaiki akhlaknya. Semakin baik akhlak seseorang, maka jalan kebahagiaan akan semakin dekat (Putri, 2018).

Kebahagiaan bukanlah suatu hal yang baru, melainkan sudah ada sejak zaman dahulu, dan telah mengalami berbagai macam perubahan konsep (Putri, 2018). Salah satu tokoh yang membahas kebahagiaan ialah Syeikh Ibnu Atha'illah as-Sakandari. Dalam pandangannya, kebahagiaan selalu erat kaitannya dengan suasana dan kondisi hati manusia. Semakin baik manusia dalam mengelola hatinya, maka kebahagiaan pun menjadi semakin tinggi. Artinya kebahagiaan sejatiya terletak di dalam diri manusia itu sendiri. Syeikh Ibnu Atha'illah mengaitkan kebahagiaan dengan kehidupan, kehidupan ini diibaratkan sebagai tempatnya berbagai macam penderitaan. Sehingga manusia tidak perlu berasumsi bahwa dunia adalah tempat berbagai macam kesenangan, karena hal tersebut dapat memutus antara hubungan hamba dengan Allah SWT. Orang yang bahagia adalah 
orang yang menjadikan dunia sebagai ladang dan bekal untuk kehidupan akhirat (Ibnu Athaillah as-Sakandari, 2013). Senada dengan apa yang dikatakan oleh Buya Hamka, bahwasannya kebahagiaan terletak pada diri manusia itu sendiri, akan tetapi tidak sedikit manusia yang meganggap kebahagiaan terletak pada kekayaan, harta, jabatan, dan kehidupan yang mewah. Alhasil, kebahagiaan sulit untuk didapatkan (Arrasyid, 2020). Sudah menjadi fitrah manusia akan terpenuhinya segala kebutuhan fisik dan materi. Namun, kebahagiaan tidak hanya terbatas dalam terpenuhinya segala kebutuhan fisik melainkan ada kebahagiaan yang paling penting yaitu kebahagiaan rohani, kepuasan dan ketenteraman hati. Haidar Bagir dalam salah satu karyanya mengatakan untuk mewujudkan kebahagiaan manusia perlu menekan kebutuhan dan mengurangi keinginan yang belum tentu tercapai (Bagir, 2015). Dengan itu, terpenuhinya kebutuhan akan menjadi semakin berkurang, demikian juga dengan ketidakbahagiaan.

Setiap tokoh mempunyai cara tersendiri dalam mendefinisikan kebahagiaan tergantung dari sudut pandang mana dan kondisi apa mereka menilai. Syeikh Ibnu Atha' illah melalui untaian hikmah di dalam kitab AlHikam, sudah tidak diragukan lagi akan kepiawaiannya dalam membahas kebahagiaan secara universal. Sehingga peneliti berusaha membahas konsep kebahagiaan menurut Syeikh Ibnu Atha'illah as-Sakandari. Tujuan penelitian ini adalah untuk mengetahui makna dan cara memperoleh kebahagiaan menurut Syeikh Ibnu Atha'illah as-Sakandari, serta relevansinya dengan kehidupan manusia di era modern. Diharapkan penelitian ini bisa memberikan sumbangsih pada khazanah ilmu pengetahuan, khususnya pada jurusan Tasawuf dan Psikoterapi. Serta menambah wawasan pada mahasiswa dalam memandang kehidupan dan mendefinisikan kebahagiaan.

\section{Metode Penelitian}

Penelitian ini adalah penelitian kualitatif yang berlandaskan pada filsafat postpositivisme dan digunakan untuk meneliti obyek alamiah. Hasil penelitiannya tidak diperoleh melalui prosedur statistik, akan tetapi melalui pengumpulan data, analisis, dan interpretasi (Albi Anggito, 2018). Berbeda halnya dengan penelitian kuantitatif yang dalam pengambilan datanya selalu menggunakan bilangan angka. Hal ini berlandaskan pada filsafat positivisme yang memandang gejala, fenomena, serta realitas sebagai sesuatu yang konkret, terukur, teramati, dan dapat diklasifikasikan. Sehingga data yang dikumpulkan menggunakan instrumen penelitian, dan analisis data yang bersifat statistik (Sugiyono, 2017).

Sumber utama dalam penelitian ini adalah kitab al-Hikam dan beberapa karya dari Syeikh Ibnu Atha'illah as-Sakandari. Selain itu, berbagai data dan informasi seperti karya Imam Ghazali, Muhammad Said 
Ramadhan al-Buthi, Hamka, dan yang lainnya dijadikan sebagai sumber data sekunder. Penelitian ini menggunakan pendekatan studi pustaka (library research). Analisis yang digunakan merupakan teknik analisis konten (content analysis). Teknik ini digunakan untuk menyimpulkan konsep atau kata yang ada di dalam teks atau rangkaian teks (Gusti Yasser Arafat, 2018). Selain itu, teknik ini dapat digunakan untuk menganalisis informasi baik tertulis, audio, dan visual. Seperti artikel, surat kabar, radio dan televisi (Afifudin, 2012). Pertama-tama peneliti mengumpulkan berbagai data dan informasi dari sumber literatur, baik primer maupun sekunder (Darmalaksana, 2020). Setelah tersaji, peneliti mengambil datadata yang sesuai untuk mempermudah penarikan sebuah kesimpulan.

\section{Hasil dan Pembahasan}

\section{Biografi Syeikh Ibnu Atha'illah as-Sakandari}

Syeikh Ibnu Atha'illah as-Sakandari lahir di Iskandariyah, Mesir. Sebuah kota yang berada di pesisir perserikatan republik Arab. Beliau lahir pada pertengahan abad ke-7 H./ ke-13 M. dan wafat pada tahun $709 \mathrm{H}$./ 1309 M. Syeikh Tajuddin Ahmad bin Muhammad bin Abdul Karim bin Abdurrahman bin Abdullah bin Ahmad bin Isa bin Husein Atha'illah asSakandari adalah nama lengkapnya. Abd al-Karim merupakan nama kakeknya yang dikenal sebagai ahli fikih pada masanya, sedangkan ayahnya bernama Muhammad Ibn Abd al-Karim merupakan pengikut setia dari Syeikh Abu Hasan asy-Syadzili. Sejak kecil, Syeikh Ibnu Atha'illah sudah mempelajari berbagai macam cabang ilmu pengetahuan terutama pemikiran-pemikiran dari Imam Malik. Perjalanan keilmuannya diawali dengan mempelajari ilmu al-Quran, tafsir, fikih, ilmu tata bahasa, serta teologi Asyariyah kepada para Syeikh di Mesir (Danner, 1999). Kecerdasan yang dimiliki oleh Syeikh Ibnu Atha'illah mampu menyita perhatian para ulama pada masa itu dan membandingkannya dengan sang kakek yang sangat terkenal dalam bidang fikih.

Pada awalnya, Syeikh Ibnu Atha'illah tidak menempuh jalan sufi seperti yang dilakukan oleh ayahnya. Namun, gencarnya gerakan sufisme pada saat itu, sangat berpengaruh terhadap spiritual beliau di masa mendatang. Sebagai ahli fikih yang terkenal, Syeikh Ibnu Atha'illah mempunyai pandangan yang jauh berbeda dengan para sufi, bahkan beliau berperan sebagai tokoh antagonis. Syeikh Ibnu Atha'illah sering beradu argumen dengan murid dari Syeikh Abul Abbas al-Mursy tokoh tarekat Syadziliyyah pada masa itu, bahkan beliau pernah mengatakan bahwa tidak ada yang perlu dicari selain hukum syariat (Danner, 1999).

Pada awal tahun 674 H./ 1276 M., Syeikh Ibnu Atha'illah pergi menemui salah seorang guru untuk mendiskusikan berbagai aspek keislaman yang berbeda. Di sanalah Syeikh Ibnu Atha'illah bertemu 
dengan Syeikh Abul Abbas al-Mursy. Tahun tersebut menjadi tahun yang sangat berpengaruh dan menjadi awal perubahan kehidupan beliau. Meskipun Syeikh Ibnu Atha'illah telah menempuh jalan tarekat, akan tetapi tidak membuatnya berhenti mempelajari ilmu hukum (fikih). Syeikh Abul Abbas al-Mursy memprediksi bahwa Syeikh Ibnu Atha'illah akan menjadi ulama besar yang faqih dan zahid. Perkataan Syeikh Abul Abbas al-Mursy menjadi kenyataan, hal ini dapat dilihat dari gelar yang disandangnya. Syeikh Ibnu Atha'illah adalah seorang imam yang diberi gelar "mahkota agama" (tajuddin), karena beliau mampu menghimpun serta memadukan kaidah-kaidah ilmu syariah dengan prinsip penyucian hati (Muhammad Said Ramadhan Al-Buthi, 2020).

Transformasi Syeikh Ibnu Atha'illah dari seorang fakih menjadi seorang guru sufi tidak mudah untuk diketahui. Nama beliau masih terkenal sebagai seorang ulama syariah yang sangat terkemuka. Akan tetapi, beliau mampu mengejawantahkan syariah dengan hakikat. Esensi pengejawantahan tersebut adalah sebagai upaya membebaskan manusia dari berbagai belenggu hawa nafsu dan keduniaan serta mampu mengangkat derajat manusia di hadapan Allah SWT (Muhammad Said Ramadhan Al-Buthi, 2020).

Akhir masa hidupnya beliau curahkan sebagai pengajar hukumhukum madzhab Maliki di Universitas al-Azhar dan madrasah-madrasah yang berada di sekitar al-Manshuriyah. Di antara muridnya yang terkenal ialah Syeikh Syihabuddin Ibn Maylaq (w. 749 H./ 1349 M.), dan Syeikh Taqiyyuddin as-Subki (w. 756 H./ 1355 M.). Syeikh Ibnu Atha'illah juga berperan sebagai Syeikh tarekat Syadziliyah yang cukup produktif dalam menuangkan buah pemikirannya dalam bentuk tulisan. Sehingga beliau menjadi guru pertama tarekat Syadziliyah yang menggunakan pena dan kertas sebagai media dalam menyebarkan dan mengklarifikasikan ajaranajaran tarekat Syadziliyah. Salah satu karyanya yang sangat terkenal ialah al-Hikam. Kitab al-Hikam merupakan magnum opus yang di dalamnya berisikan aforisme-aforisme yang menyejukan dan menggugah hati serta menjadi pijakan dasar doktrin sufi. Kitab ini merupakan kitab pertama yang ditulis sewaktu Syeikh Abul Abbas al-Mursy masih hidup. Selain itu beliau juga menulis kitab Miftah al-Falah wa Misbah al-Arwah, at-Tanwir fi Isqath at-Tadbir, Lathaif fi Manaqib Abi al-Abbas al-Mursy wa Syeikh Abi Hasan, Taj al-Arus al-Hawi li Tahdzib an-Nufus dan beberapa tulisan lainnya yang ditulis dalam bentuk risalah yakni uraian singkat dan padat (Mudin, 2016). Tulisan-tulisan di atas dianggap sebagai karya yang perenial pada dunia Islam, khususnya di kalangan umat mendatang. Meskipun Syeikh Ibnu Atha'illah telah wafat pada tahun 709 H./ 1309 M., akan tetapi corak dan otoritas karyanya selalu menarik perhatian para salik di seluruh belahan dunia (Danner, 1999). 


\section{Kebahagiaan Menurut Syeikh Ibnu Atha'illah as-Sakandari}

Kebahagiaan dilihat dari berbagai sudut pandang, masih belum mencapai titik final. Para filosof seperti Socrates, Plato, Aristoteles, dan Epicurus memandang bahwa kebahagiaan adalah puncak pencapaian tertinggi. Dimana, kebahagiaan yang dimaksudkan tidak hanya terbatas pada penilaian subjektif semata, seperti kegembiraan dan kesenangan, akan tetapi mencakup seluruh aspek kehidupan manusia meliputi sosial, moral, emosional dan spiritual (Bertens, 2015). Kebahagiaan dalam bahasa Inggris disebut dengan happy, sedangkan dalam al-Quran kebahagiaan disebut dengan istilah sa'adah, falah, najat dan najah (Hamim, 2016). Menurut Kamus Besar Bahasa Indonesia (KBBI) bahagia diartikan dengan suatu keadaan, perasaan senang dan tenteram (Dendi Sugono, 2008).

Syeikh Ibnu Atha' illah as-Sakandari memandang bahwa kebahagiaan adalah kondisi hati manusia yang selalu taat dan patuh dalam menjalankan perintah Allah dan menjauhi segala larangan-Nya (Ibnu Atha'illah asSakandari, 2003). Kebahagiaan yang dimaksud merujuk pada kebahagiaan dua dimensi, yaitu kebahagiaan di dunia dan kebahagiaan di akhirat. Karakteristik orang yang bahagia, selalu tercermin dari kondisi dan situasi hati. Kondisi hati sangat berpengaruh terhadap kebahagiaan, karena hati merupakan sumber dari kebahagiaan dan penderitaan (Muhammad Said Ramadhan al-Buthi, 2020).

Konsep kebahagiaan tidak hanya terfokus pada kebahagiaan dunia, akan tetapi dibahas pula konsep kebahagiaan di akhirat, sama halnya dengan yang disampaikan oleh Syeikh Ibnu Atha'illah as-Sakandari. Dunia merupakan tempat yang amat berpengaruh dalam tercapainya kebahagiaan, baik di dunia maupun di akhirat. Syeikh Ibnu Atha'illah asSakandari menyampaikan, ada dua tipe manusia dalam menyikapi dunia. Kedua tipe ini sangat berpengaruh terhadap kebahagiaan yang hendak dicapai manusia. Pertama, manusia yang mengatur dunia untuk urusan dunia. Kedua, manusia yang mengatur urusan dunia untuk keperluan akhirat. Tipe manusia pertama, menggambarkan ketamakan manusia, yang senantiasa mengumpulkan harta demi kesenangan semata, tanpa memandang aspek kehalalan dan keharamannya. Tipe ini menurut Syeikh Ibnu Atha'illah as-Sakandari tidak akan mengantarkan pada kebahagiaan, sebaliknya, sikap tersebut hanya akan mengantarkan manusia pada ketamakan dan kehancuran, karena tujuan utama yang ingin diperolehnya ialah memperkaya diri. Jika hartanya semakin bertambah, maka ia akan semakin terlena dan lupa kepada Allah SWT, sebaliknya jika hartanya hilang dan berkurang menyebabkan kesedihan yang luar biasa, seperti halnya realita yang ditemukan dalam kehidupan ini. Ikhtiar dalam mencari urusan dunia merupakan esensi dari tipe manusia yang kedua. Orang yang mengurus urusan dunia untuk keperluan akhirat dan ibadahnya, tidak dilandasi tujuan untuk menimbun harta dan menguasai dunia. Hal tersebut 
dilakukannya semata-mata hanya untuk memenuhi kebutuhan dan keridaannya. Manusia tipe kedua ini sangat memahami, bahwa dunia adalah ujian dan fitnah besar. Ia jadikan dunia sebagai media untuk memperoleh kebahagiaan dan keberuntungan di akhirat (Ibnu Atha'illah As-Sakandari, 2013).

Konsep kebahagiaan Syeikh Ibnu Atha'illah dituangkan dalam berbagai tulisan yang bisa kita temukan dalam karya-karyanya. Kitab alHikam merupakan salah satu kitab yang ditulis oleh Syeikh Ibnu Atha'illah as-Sakandari. Di dalamnya terdapat banyak aforisme yang menggugah dan menyejukan hati. Konsep kebahagiaan pun disajikan lewat aforismenya di dalam kitab al-Hikam, dan beberapa karya yang lainnya. Konsep kebahagiaan yang pertama, dijelaskan dalam hikmah ke-24, yang berbunyi:

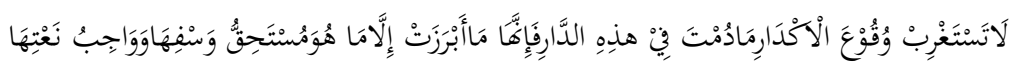

Artinya: Janganlah engkau merasa heran dengan banyaknya kekeruhan yang dijumpai selama masih hidup di dunia. Sebab dunia ini adalah tempat untuk menampakan berbagai hal yang layak disifati dengan kekeruhan, dan hal-hal yang seharusnya digambarkan demikian (Ashim Ibrahim al-Kayyali, 2018, p. 47).

Hikmah di atas berkaitan dengan karakteristik kehidupan. Dalam pandangan Islam, kehidupan manusia terbagi ke dalam dua aspek penting yaitu aspek duniawi dan aspek ukhrowi. Kedua aspek ini sangat dibutuhkan manusia dalam menjalani kehidupannya. Keseimbangan antara keduanya menjadi tolak ukur untuk mencapai kehidupan yang harmonis serta tercukupinya kebutuhan jasmani dan rohani. Pada kenyataannya, masyarakat Islam pada khususnya masih belum mampu merealisasikan kedua aspek tersebut karena ketidakpahaman akan hakikat kehidupan itu sendiri (M. Ma'ruf, 2019).

Hikmah Syeikh Ibnu Atha'illah ini, menjelaskan bahwa kelaziman dari karakteristik dunia adalah tempat berbagai kesulitan dan penderitaan. Hikmah ini senada dengan apa yang dikakatakan oleh Ja'far ash-Shadiq bahwa barang siapa yang mencari sesuatu yang belum pernah diciptakannya, sama saja dengan menyiksa diri sendiri karena tidak akan pernah mendapatkannya. Lalu, ditanyakan apa yang tidak akan pernah didapatkannya itu? Ja'far ash-Shadiq menjawab, "kenyamanan di dunia" (Ibnu Atha'illah as-Sakandari, 2018). Hikmah ini menegaskan sebuah kenyataan bahwa kenikmatan dunia seringkali bercampur dengan kebahagiaan-kebahagiaan yang bersifat intimidasi. Menurut Syeikh Ibnu Atha'illah, Allah menakdirkan dunia dengan sifat dan kondisi seperti itu, setidaknya terdapat dua hikmah yang terkandung di dalamnya. 
Pertama, Allah menjadikan dunia ini sebagai tempat ujian dan medan yang penuh dengan beban, adalah untuk menginformasikan kembali tujuan diciptakannya manusia. Urgensi dari penciptaan manusia dalam segala aspek kehidupan ini adalah untuk mempraktikan bukti penghambaannya kepada Allah SWT. Baik dilakukan dengan cara patuh terhadap segala perintahnya, hukum-hukumya, maupun dengan cara tunduk terhadap segala kekuasannya. Ketika manusia berasumsi bahwa kehidupan ini hanya berisi dengan kenikmatan dan kebahagiaan, terhindar dari kekeruhan dan beban penderitaan, maka dengan cara apa manusia akan merespon penghambaannya kepada Allah SWT. Padahal, bentuk dan cara penghambaan manusia kepada Allah selalu bersifat pilihan (Al-Buthi, 2020).

Manusia adalah makhluk yang mempunyai beban kewajiban. Praktik penghambaan manusia adalah buah dari pembebanan (taklif) tersebut. Tidak dikatakan pembebanan jika dalam prosesnya tidak ada kesulitan dan beban yang ditanggungnya. Muhammad Said Ramadhan al-Buthi dalam kitabnya al-Hikam al-Atha'iyyah mengatakan, jika perjalanan kehidupan hanya sekadar kehidupan yang datar dan monoton, dengan dibaluti oleh kenikmatan dan kebahagiaan semata, itu merupakan sebuah kontradiksi (Muhammad Said Ramadhan al-Buthi, 2020). Karena letak pembebanan seorang hamba menjadi tidak tampak. Buah dari pembebanan yang dimaksud oleh Syeikh Ibnu Atha'illah adalah kesabaran dan rasa bersyukur. Dengan kedua beban inilah manusia mempraktikan penghambaannya kepada Allah SWT. Sebagaimana firman Allah SWT, yang berbunyi:

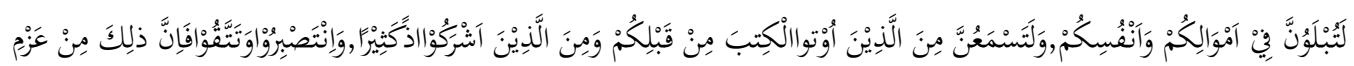

Artinya: Kamu benar-benar akan diuji dengan hartamu dan dirimu. Dan kamu benar-benar akan mendengar banyak hal yang menyakitkan hati dari orang-orang yang diberi kitab sebelum kamu dan dari orang-orang musyrik. Jika kamu bersabar dan bertakwa, sesungguhnya yang demikian itu adalah urusan yang diutamakan (QS. Ali-Imraan: 186).

Kedua, kehidupan dunia hanya kehidupan sementara dan dibatasi dengan ujian. Alur kehidupan tidak selamanya bersifat nikmat dan senang. Tetapi selalu diiringi dengan berbagai kesulitan dan kekeruhan. Ujian yang diterima manusia sewaktu di dunia adalah untuk memperoleh reward atau balasan menghadapi kehidupan akhirat. Senada dengan apa yang dikatakan oleh Abd Al-Qadir Abu al-Faris, bahwa kehidupan di dunia adalah medan segala bentuk ujian dan akhirat adalah tempat memperoleh 
balasan (Lilik Ummi Kultsum, 2018). Kehidupan dunia hanya membuat manusia terlena dan lupa akan balasan terbesar Allah SWT, berupa kebahagiaan di akhirat. Dalam pandangan Syeikh Ibnu Atha'illah, kehidupan dan manusia mempunyai hubungan yang sangat erat. Hubungan tersebut dibangun atas dasar kasih sayang dan kelemahlembutan. Kehidupan dunia adalah titipan dari Allah SWT, artinya manusia harus menyayangi kehidupan ini atas dasar kasih sayang-Nya. Tidak menjadikan kehidupan dunia terus melekat pada hatinya, dan tidak mempunyai rasa penyesalan ketika meninggalkannya (Muhammad Said Ramadhan al-Buthi, 2020).

Selama menjalani kehidupan, manusia tidak akan terlepas dari urusan-urusan dunia. Syeikh Ibnu Atha'illah menyebutnya dengan alaghyar (Muhammad Said Ramadhan al-Buthi, 2020). Bahkan, manusia dituntut untuk senantiasa berkecimpung di dalamnya. Menjadikan kehidupan dunia sebagai ladang untuk meraih dan menggapi rida-Nya, merupakan kewajiban manusia. Senada dengan apa yang dikatakan oleh Imam al-Ghazali, kebahagiaan dunia adalah jalan untuk bisa merasakan kebahagiaan di akhirat, karenanya menjadi kewajiban manusia untuk mengenali dunia, ilmu-ilmu dunia, dan karakteristik yang ada di dalamnya. Perilaku menjauhi dan tidak mengenal dunia sama saja dengan menjauhkan manusia dari kebahagiaan hidup di dunia (Rusfian Effendi, 2017).

Syeikh Ibnu Atha'illah tidak menyarankan manusia untuk lari meninggalkan kehidupan dunia. Hanya saja, kehidupan manusia jangan sampai menjadikan manusia tunduk pada keinginan-keinginan hawa nafsu yang sementara. Para ulama menyebutnya dengan istilah al-Khalwah fi alJilah. Maksud dari istilah tersebut, menurut Syeikh Ibnu Atha'illah bukan khalwat dalam arti menyendiri dan meninggalkan keramaian dunia dan masyarakat sekitar. Tetapi, khalwat yang disyariatkan dan dicintai-Nya ialah terjun langsung dalam kehidupan dunia tetapi tidak hanyut dan tidak terlena. Artinya manusia harus menjadi pemeran utama dalam mengatur dan mengendalikan kehidupan dunia, bukan manusia yang dikendalikan oleh kehidupan dunia. Lari dari berbagai urusan dan kekeruhan dunia, tidak termasuk solusi. Menurut Syeikh Ibnu Atha'illah perilaku tersebut mencerminkan orang yang tidak tahu akan hakikat kehidupan dunia. Kekeruhan dan segala urusan bisa memutuskan hubungan baik antara sesama manusia, bahkan memutuskan hubungan manusia dengan Allah SWT, bahkan diri manusia sendiri pun termasuk urusan dan kekeruhan dunia. Kekeruhan yang dimaksud oleh Syeikh Ibnu Atha'illah tidak hanya sebatas materi semata, termasuk kekeruhan yang bersifat immateri. Ketidaktahuan akan hakikat ini, mampu mendorong manusia untuk lari dari kenyataan, bahkan manusia mengatakan "aku akan lari dan membebaskan diri dari kekeruhan dan urusan ini, lalu akan menyendiri 
dan menyepi ditengah-tengah sunyi" (Muhammad Said Ramadhan alButhi, 2020).

Kesadaran dan pengetahuan manusia begitu dibutuhkan dalam menghadapi kenyataan hidup. Dengan demikian, manusia akan mampu menerima berbagai kondisi, baik senang maupun susah. Ia akan menjalaninya dengan penuh keihklasan dan kedamaian. Orang yang memahami realitas kehidupan di dunia ini, akan terus merasakan ketenangan baik ketika mendapatkan kenikmatatan maupun ketika dilanda kekeruhan termasuk kesengsaraan dan kesedihan. Karena itulah hakikat dan karakter dari kehidupan dunia.

Konsep kebahagiaan Syeikh Ibnu Atha'illah as-Sakandari yang kedua, terdapat dalam hikmah yang ke-228, yang berbunyi:

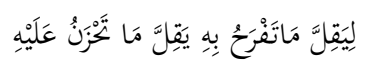

Artinya: Tatkala berkurang apa yang membuatmu senang, maka berkurang pula apa yang membuatmu bersedih (Ibnu Atha'illah asSakandari, 2018, p. 339).

Hikmah di atas secara fundamental mengajarkan bahwa kebahagiaan sangatlah mudah untuk dicapai. Kebahagiaan dan kesedihan merupakan dua kata yang saling kontradiksi. Namun menurut hikmah di atas, kedua kata tersebut mempunyai pengaruh dan bobot yang sama. Ketika kebahagiaan disimpan dalam bentuk sesuatu dan terlampau besar, maka potensi kesedihan pun akan semakin besar. Sebaliknya, jika kebahagiaan yang disimpan terhadap sesuatu itu sedikit, maka potensi kesedihan pun juga sedikit. Hubungan tersebut mempunyai sebab akibat yang setimpal, meskipun keduanya saling berlawanan (Ibnu Atha'illah as-Sakandari, 2018).

Upaya mengurangi harta dan sebab yang lainnya, merupakan langkah dalam mengurangi kesedihan. Sikap seperti ini merupakan cerminan orang yang telah sempurna akalnya dan pandangannya. Orang seperti ini tidak hanya mengambil maslahat berupa kebahagiaan dari sesuatu yang keberadaannya hanya sementara, sehingga terhindarnya dari kerusakan akibat kesedihan adalah kebahagiaan. Seperti perkataan orang yang bijak bahwa "menghindari kerusakan lebih utama daripada mencari kemaslahatan," termasuk mengurangi kesenangan demi berkurangnya kesedihan.

Oleh karena itu, Syeikh Ibnu Atha'illah as-Sakandari memberikan jalan agar manusia senantiasa mensyukuri nikmat yang telah Allah berikan. Sikap merasa tidak cukup atas segala kebutuhan hidup, akan membuat manusia sibuk dan lalai terhadap kewajibannya, sehingga 
tindakan seperti itu akan menjadikannya berlebihan (thugyan) terutama dalam masalah harta benda. Seperti sabda Nabi Muhammad Saw yang berbunyi: "sesuatu yang sedikit dan cukup lebih baik dan utama daripada sesuatu yang banyak tetapi melalaikan" (HR. Abu Ya'la dan adh-Dhiya). Di dalam hikmah sebelumnya, Syeikh Ibnu Atha'illah as-Sakandari berkata:

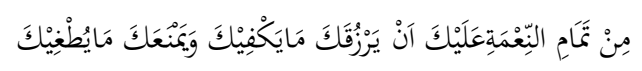

Artinya: Di antara bentuk kesempurnaan nikmat yang diberikan Allah kepadamu ialah memberi kecukupan terhadap segala kebutuhan dan menghindarkan dari sesuatu yang menyebabkan kecelakaan atasmu (Ibnu Atha'illah as-Sakandari, 2018, p. 338).

Mengetahui kesempurnaan nikmat yang telah diberikan-Nya, akan mendorong manusia untuk selalu merasa cukup atas apa yang telah diberikan-Nya. Dengan kata lain, manusia akan selalu bahagia atas nikmat dan kecukupan yang diperolehnya. Keyakinan terhadap karunia yang telah Allah tentukan dan pasti diberikan, akan menjadikan manusia sibuk dengan perintah Allah dari pada mengurus apa yang sudah dijamin-Nya. Dengan demikian, Allah akan mengangkat derajatnya, mencukupkan segala kebutuhannya, dan menyempurnakan cahaya ilahi-Nya (makrifat) (Ibnu Atha'illah al-Sakandari, 2013). Dengan bermakrifat kepada Allah SWT, manusia akan sampai pada derajat kebahagiaan yang hakiki.

\section{Korelasi Kebahagiaan dengan Akhlak}

Menurut Syeikh Ibnu Atha'illah, akhlak bisa mengantarkan manusia menjangkau dirinya sendiri, karenanya manusia harus menyadari bahwa ia mempunyai tujuan hidup. Akhlak yang dimaksud tidak hanya terbatas pada aspek lahiriyah yang sifatnya horizontal, akan tetapi juga menyangkut akhlak bathiniyyah yang bersifat vertikal. Akhlak merupakan sifat terdidik yang dimiliki oleh manusia serta mampu mengantarkannya menjadi manusia yang paripurna. Selain itu, Imam al-Ghazali berpendapat, bahwa pendidikan akhlak yang mulia akan mengantarkan manusia memperoleh kebahagiaan di dunia maupun di akhirat (Alimudin \& Darifah, 2018).

Manusia merupakan makhluk yang memiliki pengaruh terhadap kehidupan. Manusia dibekali akal sebagai sarana untuk mengetahui dan hati sebagai tempat berkumpulnya emosi dan perasaan. Faktor inilah yang membedakan antara manusia dengan makhluk ciptaan yang lainnya. Manusia akan mencapai derajat kemanusiannya ketika kedua potensi ini telah teraktualisasikan, dengan demikian manusia akan merasakan kebahagiaan. Akal dan hati seyogianya harus bersinergi dalam menghasilkan moral atau etika. Moral atau etika seperti inilah yang akan mengantarkan manusia kepada kebahagiaan. Demikianlah korelasi antara 
moral dengan kebahagiaan yang dikonsepsikan oleh Aristoteles (Hasib, 2019).

Imam Al-Ghazali mengatakan bahwa hati mempunyai perilaku yang beragam. Sebagian perilaku disebut dengan budi pekerti buruk (akhlaq as$s u^{\prime}$ ), dan sebagian lagi disebut dengan budi pekerti baik (akhlaq al-hasanah). Budi pekerti yang baik mengantarkan manusia mencapai derajat kebahagiaan yang hakiki. Sedangkan, budi pekerti yang buruk menyebabkan manusia mengalami kehancuran dan penderitaan (Abu Hamid al-Ghazali, 2020).

Perbedaan antara orang yang bahagia dengan orang yang menderita dijelaskan dalam salah satu firman-Nya yang berbunyi:

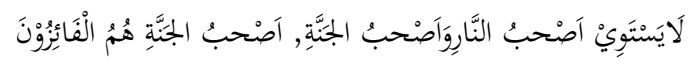

Artinya: Tidaklah sama antara penghuni neraka dengan penghuni surga, penghuni-penghuni surgalah yang memperoleh kemenangan" (QS. Al-Hasyr: 20).

Berdasarkan ayat di atas, Syeikh Ibnu Atha'illah menjelaskan bahwa terdapat perbedaan yang sangat jauh antara orang yang memperoleh kebahagiaan dengan orang yang memperoleh penderitaan.

Orang bahagia dalam pandangan Syeikh Ibnu Atha'illah adalah orang yang hatinya bersinar. Pengejawantahan hati yang selalu bersinar akan tampak ketika manusia melihat suatu kemaksiatan. Ia akan menolak, mengingkari, serta berusaha untuk mengajak pada kebaikan dan memohonkan ampunan. Sebaliknya, sikap orang yang menderita senantiasa menyudutkan dan mencela para pelaku maksiat. Dalam hatinya telah tertanam rasa benci, sehingga membuatnya melakukan hal yang tidak terpuji, seperti mencela, memfitnah bahkan melaknatnya (Ibnu Atha'illah as-Sakandari, 2003).

Selain itu, Syeikh Ibnu Atha'illah juga menjelaskan bahwa orang bahagia senantiasa menjaga kesucian diri, tidak mendzalimi orang lain, serta menjaga rahasia, aib, dan memelihara harga diri orang lain. Dengan demikian orang tersebut akan mendapatkan kebahagiaan dan ketenangan. Orang yang mampu menahan diri untuk tidak mendzalimi orang lain dari pagi hingga menjelang petang, menurut Syeikh Ibnu Atha'illah asSakandari adalah orang yang mendapatkan kebahagiaan. Jika mampu menahan kedzaliman terhadap diri sendiri dan terhadap perintah-perintah Allah, maka orang tersebut telah mendapatkan kebahagiaan yang sempurna. Puncak dari kesempurnaan kebahagiaan itu ditandai dengan berjumpa dengan Allah dalam keadaan iman. Orang yang mendzalimi 
orang lain sama halnya dengan membuat kesedihan untuk akhirat (Ibnu Athaillah as-Sakandari, 2003).

\section{Urgensi Konsep Kebahagiaan Syeikh Ibnu Atha'illah di Era Modern}

Tolak ukur kebahagiaan di era modern seperti sekarang ini, bisa dilihat dari seberapa banyak penguasaan terhadap materi. Hal ini bisa dilihat dari gaya hidup yang cenderung hedonis dan materialistik (Maryam Ismail, 2019). Tujuan utama pola hidup yang seperti ini tiada lain adalah untuk mendapatkan kesenangan dan kebahagiaan semata. Pada umumnya, kebahagiaan dilihat dari seberapa kaya, sukses, dan bisa menikmati berbagai kesenangan. Tidak heran, banyak manusia yang terpesona untuk memiliki salah satu bahkan ketiganya sekaligus. Harta kekayaan dan kesenangan berpotensi menurunkan kebahagiaan serta menjadi sumber penderitaan dan kejenuhan (Jalaluddin Rakhmat, 2009). Kehidupan manusia modern yang menyuguhkan kehidupan materi dan individualistik, tidak memberikan rasa nyaman dan bahagia. Sebaliknya, angka kriminalitas yang semakin tinggi sebagai cerminan dari krisis moral yang terjadi (Dewi, 2017).

Melihat realita seperti di atas, konsep kebahagiaan yang disuguhkan oleh Syeikh Ibnu Atha'illah as-Sakandari begitu penting untuk diterapkan saat ini. Orientasi kebahagiaan yang diletakkan dalam bentuk kesenangan seperti uang, jabatan, serta kebutuhan ekonomi yang tercukupi, pada kenyataannya belum mampu memberikan hasil sesuai yang diharapkan. Salah satu contoh seperti yang terjadi di negara-negara Barat, kebahagiaan semakin menurun seiring dengan pertumbuhan perekonomian yang semakin cepat (Jalaluddin Rakhmat, 2009).

Pergeseran paradigma mengenai kebahagiaan, lagi-lagi tidak terlepas dari asumsi yang mengatakan bahwa uang dan pendapatan merupakan sumber kebahagiaan. Tidak heran, hal ini masih menjadi perdebatan di semua kalangan, termasuk ekonom dan psikolog. Hal menarik dari perdebatan ini ialah timbulnya sebuah istilah yang dinamakan dengan "paradoks Easterlin" atau konsep titik jenuh yang digagas oleh Easterlin (1974). Pada awalnya, pendapatan seseorang berbanding lurus dengan tingkat kebahagiaan, dengan logika semakin besar pendapatan semakin terpenuhinya segala kebutuhan. Akan tetapi, pada akhirnya relasi tersebut akan sampai pada sebuah titik yang dinamakan dengan titik jenuh. Lonjakan ekonomi yang terjadi di negara-negara maju, seperti Amerika, Eropa, Jepang, selama beberapa tahun terakhir tidak diiringi dengan peningkatan kebahagiaan masyarakat di negara tersebut (Muskinul Fuad, 2018).

Di era modern, kesuksesan yang tidak sejalan dengan kebahagiaan tidak lagi menjadi sebuah pengecualian (anomali), akan tetapi sudah menjadi sesuatu yang normal dan sering terjadi. Hilangnya energi 
kehidupan serta timbulnya rasa sedih di tengah kehidupan yang tampak bahagia, sering disebut dengan istilah dysthymia (Jalaluddin Rakhmat, 2009). Gejala lain yang mencerminkan kehidupan di era modern ialah gangguan kecemasan, para psikolog menyebutnya dengan istilah anxiety disorder. Fenomena seperti ini, menurut Bastaman merupakan representasi dari kehidupan manusia di zaman modern, sehingga abad ini disebut dengan abad kecemasan (the age of anxiety). Akibatnya, terjadilah krisis multi dimensi yang meliputi perekonomian, politik, sosial, budaya, dan lingkungan masyarakat dunia. Tidak heran banyak manusia yang mengalami penderitaan, karena kegagalannya dalam menggapai kehidupan dan kebahagiaan (Muskinul Fuad, 2018).

Melihat realita seperti ini, Syeikh Ibnu Atha'illah melalui konsep kebahagiaannya yang sederhana, mengajarkan kepada kita supaya tidak menaruh kebahagiaan pada sesuatu yang sifatnya sementara. Seperti yang telah dijelaskan sebelumnya, kebahagiaan bukanlah kesenangan dan kenikmatan semata, tidak sedikit orang yang dipenuhi dengan berbagai kenikmatan tetapi dia tidak merasakan kebahagiaan. Dengan mengenal sifat dunia dan karakteristiknya, seyogianya manusia tidak terlalu berambisi dalam segala hal. Esensi kebahagiaan itu sendiri terletak dalam hati manusia, karena itu Syeikh Ibnu Atha'illah mengajarkan kepada kita supaya menjaga hati agar tidak terlena terhadap sesuatu yang memikat tetapi pada akhirnya menjemukan (Ibnu Atha'illah as-Sakandari, 2018). Memperbaiki akhlak begitu penting untuk dilakukan, sebagai upaya timbulnya rasa nyaman, dengan demikian kebahagiaan akan mudah didapatkan (Putri, 2018).

\section{Kesimpulan}

Syeikh Ibnu Atha'illah merupakan seorang sufi yang sangat faqih. Beliau mampu memadukan ilmu-ilmu syariat dan ilmu-ilmu hakikat. Kata Syeikh disematkan pada nama Ibnu Atha'illah as-Sakandari sebagai penghormatan akan kebesaran nama beliau. Syeikh Ibnu Atha'illah asSakandari melalui hikmah-hikmah yang terkandung di dalam kitab alHikam, dan kitab-kitab yang lainnya, menginformasikan bahwa untuk mencapai kebahagiaan, manusia perlu mengolah hati dan memperbaiki akhlak, baik akhlak terhadap sesama manusia maupun akhlak terhadap Allah SWT. Selain itu, Syeikh Ibnu Atha'illah mengharuskan manusia agar mengetahui kesempurnaan nikmat yang telah diberikan Allah SWT, sebagai upaya agar manusia tetap bersyukur dan bersabar atas apa yang dimilikinya. Konsep kebahagiaan Syeikh Ibnu Atha'illah sangat relevan dengan kehidupan manusia di era modern ini, konsep yang sederhana namun mampu memberikan rasa nyaman, tenteram, dan mengantarkan kepada kebahagiaan yang sejati. Penelitian ini diharapkan dapat memberikan manfaat, terkhusus bagi penulis umumnya bagi khalayak 
umum yang masih bingung dan terus mencari makna kebahagiaan. Juga diharapkan menjadi referensi dan pembanding dalam menjalani kehidupan dan tercapainya tujuan hidup yang bermakna. Dalam menjalani rangkaian penelitian, peneliti dihadapkan dengan beberapa keterbatasan, antara lain kajian ini hanya menggunakan kitab Syarh al-Hikam sebagai rujukan utama dikarenakan peneliti tidak memperoleh kitab asli yaitu Matan al-Hikam, serta keterbatasan referensi dari kitab-kitab karangan Syeikh Ibnu Atha'illah as-Sakandari yang sudah jarang beredar sehingga peneliti kesulitan untuk menghimpun karya-karya beliau. Keterbatasan ini peneliti paparkan sebagai ruang penyempurnaan bagi peneliti selanjutnya agar studi yang dilakukan bisa lebih baik. Semoga penulis dan pembaca mendapat rida dan keberkahan dari Allah SWT.

\section{Daftar Pustaka}

Abu Hamid al-Ghazali. (2020). Kimiya al-Sa'adah (Mustofa Bisri (ed.); Cetakan 1). Jakarta: PT Qaf Media Kreativa.

Afifudin. (2012). Metode Penelitian Kualitatif. Bandung: CV Pustaka Setia.

Albi Anggito, J. S. (2018). Metodologi Penelitian Kualitatif (E. D. Lestari (ed.); Cetakan 1). Sukabumi: CV Jejak.

Arrasyid, A. (2020). Konsep Kebahagiaan dalam Tasawuf Modern Hamka. Refleksi: Jurnal Filsafat dan Pemikiran Islam, 19(2), 205-220. https:/ / doi.org/10.14421/ref.2019.1902-05

Ashim Ibrahim al-Kayyali. (2018). Al-Lathaif al-Ilahiyyah fi Syarh Mukhtarat min al-Hikam al-Atha'iyyah (M. Tatam Wijaya (ed.); Cetakan 1). Jakarta: PT Qaf Media Kreativa.

Bagir, H. (2015). Risalah Cinta dan Kebahagiaan (II). Bandung: Mizan.

Bertens, K. (2015). Etika (Cetakan 3). Bandung: Kanisius.

Danner, V. (1999). Mistisisme Ibnu Atha'illah: Wacana Sufistik Kajian Kitab alHikam (cetakan 1). Risalah Gusti.

Darmalaksana, W. (2020). Metode Penelitian Kualitatif Studi Pustaka dan Studi Lapangan. Pre-Print Digital Library UIN Sunan Gunung Djati Bandung, 1-6.

Dendi Sugono, D. (2008). Kamus Bahasa Indonesia. Pusat Bahasa Departemen Pendidikan Nasional.

Dewi, E. (2017). Konstruksi Kebahagiaan dalam Bingkai Kecerdasan Spritual. Substantia: Jurnal Ilmu-Ilmu Ushuluddin, 19, 133-148. https:/ /jurnal.ar-

raniry.ac.id/index.php/substantia/article/view/2881

Gusti Yasser Arafat. (2018). Membongkar Isi Pesan dan Media dengan Content Analysis. Jurnal Al-Hadharah, 17(33), 32-48.

Haidar Bagir. (2006). Buku Saku Filsafat Islam. Bandung: Mizan.

Hamim, K. (2016). Kebahagiaan dalam Perspektif Al-Qur'an dan Filsafat. Tasâmuh, 13(2), 127-150. 
Hasib, K. (2019). Manusia dan Kebahagiaan: Pandangan Filsafat Yunani dan Respon Syed Muhammad Naquib al-Attas. TASHFIYAH: Jurnal Pemikiran Islam, 3(51), 21-40.

Ibnu Atha'illah al-Sakandari. (2013). Bahjat al-Nufus (F. F. Bahreisy (ed.); Cetakan 1). Jakarta: Zaman.

Ibnu Atha' illah as-Sakandari. (2003). Bahjah Al-Nufus (C. R. B. A. Cecep Alba (ed.); Cetakan 1). Bandung: PT Remaja Rosdakarya.

Ibnu Atha'illah as-Sakandari. (2013). At-Tanwir Fii Isqaati at-Tadbir (Misbah El-Majid (ed.); Cetakan 1). Surabaya: Pustaka Hikmah Perdana.

Ibnu Atha'illah as-Sakandari. (2018). Syarh al-Hikam Ibnu ath-Thaillah asSakandari (Imam Firdaus (ed.); Cetakan 3). Bandung: Wali Pustaka.

Ibnu Athaillah as-Sakandari. (2003). Menjaga Kesucian Kalbu (C. R. B. A. Cecep Alba (ed.); Cetakan 1). Bandung: Remaja Rosdakarya.

Ibnu Athaillah as-Sakandari. (2013). At-Tanwir fi Isqaati at-Tadbir (M. ElMajid (ed.); Cetakan 1). Surabaya: Pustaka Hikmah Perdana.

Ida Rodiah. (2017). Konsep Kebahagiaan Menurut Hamka. UIN Sunan Gunung Djati.

Iman Setiadi Arif. (2018). Psikologi Positif: Pendekatan Saintifik Menuju Kebahagiaan (Cetakan 2). Bandung: PT Gramedia Pustaka Utama.

Jalaluddin Rakhmat. (2009). Meraih Kebahagiaan. Simbiosa Rekatama Media. Jarman Arroisi. (2019). Bahagia dalam Perspektif Al-Ghazali. Jurnal Studi Agama-Agama Dan Pemikiran Islam, 17(01).

Lilik Ummi Kultsum. (2018). Cobaan Hidup dalam Al-Quran (Studi AyatAyat Fitnah dengan Aplikasi Metode Tafsir Tematik). Ilmu Ushuluddin, 5(2), 107-138.

Ma'ruf, M. (2019). Konsep Mewujudkan Keseimbangan Hidup Manusia dalam Sistem Pendidikan Islam. Jurnal Al-Makrifat, 4(2).

Maryam Ismail. (2019). Hedonisme dan Pola Hidup Islam. Jurnal Ilmiah Islamic Resources FAI-UMI Makassar, 16(2), 193-204.

Mudin, M. I. (2016). Konsep Makrifat Ibnu Athaillah al-Sakandari. Kalimah: Jurnal Studi Agama Dan Pemikiran Islam, 14(2), 156-172.

Muhammad Said Ramadhan al-Buthi. (2020). Al-Hikam al-Athaiyyah: Syarah al-Hikam Ibnu ath-Thaillah as-Sakandari (A. U. Abdurrahman Jufri, Hadiri Abdurrazaq (ed.); Cetakan 1). Tangerang: Pustaka IIMaN.

Muskinul Fuad. (2018). Psikologi Kebahagiaan dalam Al-Quran (Cetakan 1). Yogyakarta: Lontar Mediatama.

Putri, E. W. (2018). Konsep Kebahagiaan dalam Perspektif AlFarabi. THAQAFIYYAT: Jurnal Bahasa, Peradaban dan Informasi Islam, 19(1), 95-111.

Rusfian Effendi. (2017). Filsafat Kebahagiaan (Plato, Aristoteles, Al-Ghazali, AlFarabi) (cetakan 1). Yogyakarta: Deeppublish. 
Slamet, I. (2018). Konsep Pendidikan Akhlak Menurut Syekh Ibnu 'Athaillah As-Sakandari dalam Kitabnya al-Hikam. Studi Pendidikan Islam, 18(1).

Sugiyono. (2017). Metode Penelitian Kombinasi (Mixed Methods). Bandung: CV Alfabeta.

Tamami. (2011). Psikologi Tasawuf. Bandung: Pustaka Setia. 